\title{
ЮРИДИЧЕСКАЯ КОНСТРУКЦИЯ НЕОСТОРОЖНЫХ ПРЕСТУПЛЕНИЙ НУЖДАЕТСЯ В СОВЕРШЕНСТВОВАНИИ
}

Аннотация: Уголовный закон считается одним из самых мощуных средств противодействия негативным социальным явлениям. При этом в России он легко поддается корректировке. Вместе с тем, показатели уголовной статистики за прошедшие 40 лет позволяют усомниться в его способности оказывать положстельное влияние на состояние неосторожной преступности. Основной причиной охранительно-регулятивной дисфункции уголовного закона являются недостатки юридической конструкции, на базе которой построено большинство статей Особенной части УК РФ о неосторожных преступлениях. Использование структурно-функционального подхода и отдельныхметодов лингвистики позволяет выявить основные недостатки юридической конструкции неосторожных преступлений, а также негативные явления, возникшие в судебно-следственной практике в результате её применения. В существующем виде уголовный закон позволяет обосновать юридическую ответственность в самых разнообразных случаях неосторожного причинения вреда, однако не учитывает важных особенностей общественного и индивидуального сознания своих адресатов. Смысловой фокус уголовно-правовых запретов оказался смещённым в сторону от произвольных единиц поведения и сочиально-психологических установок, которые надлежало бы вытеснить из социальной практики. Это ведёт к применению уголовного закона по правилам объективного вменения, к выраженному внижению его общепредупредительного потенциала и ряду других нежелательньх последствий. В заключительной части статьи сформулировано шесть предложений по совершенствованию юридической конструкции, позволяющих сделать уголовный закон более эффективным средством охраны общественных отношений от неосторожного их нарушения. Abstract: Criminal law is regarded as one of the strongest means against negative social manifestations. In Russia it is easily amended. At the same time, the criminal statistical data in the last 40 years make one doubt its capability of positive influence upon the situation in the sphere of negligent crimes. The main causes for the protective and regulatory malfunction of the criminal law are shortcomings of the legal construction, which serves as the basis for the most articles in the Special Part of the Criminal Code of the Russian Federation on negligent crimes. The use of structural-functional approach and some linguistic methods allow to uncover the main defects of the legal construction of negligent crimes, as well as negative matters in judicial and investigative practice due to its application. The current provisions of criminal law allow to substantiate for the legal responsibility in various situations of negligent causation of harm, however, it fails to give due regard to the important features of social and individual conscience of the addressees. The semantic focus of the criminal legal prohibition was moved away from the voluntary activity units and social psychological settings, which need to be pressed out of the social practice. It leads to application of criminal law through the rules of the strict liability and lowering of its general preventive potential, as well as to the number of other undesirable consequences. In the final part of the article the author formulates six propositions for the improvement of legal construction, allowing to make criminal law more efficient for the purpose of protection of social relation from negligent violations.

Ключевые слова: Уголовная ответственность, дифференциация ответственности, юридические конструкиии, неосторожность, охранительная функиия, уголовный закон, юридическая техника, неосторожная преступность, причинная связь, объективное вменение.

Keywords: Criminal responsibility, differentiation of responsibility, legal constructions, negligence, protective functions, criminal law, legal technique, negligent crime, causal link, strict liability.

бщественная потребность в применении мер юридической ответственности за неосторожное причинение вреда обозначилась достаточно давно и отражена во многих памятниках права. То, что в современном уголовном законодательстве можно выделить целую подсистему норм о преступлениях, совершаемых по неосторожности, ни у кого удивления не вызы- 
DOI: $10.7256 / 1811-9018.2014 .4 .11438$

При цитировании этой статьи сноска на доі обязательна

\section{Право и политика 4 (172) 2014}

вает и представляется совершенно необходимым уголовно-политическим решением.

Очевидным выглядит и утверждение, что уровень защищённости жизненно важных интересов граждан, общества и государства зависит не от одних лишь охранительных уголовно-правовых норм, какими бы суровыми они не оказались. Уровень и динамика неосторожной преступности определяется взаимодействием трёх составляющих. Во-первых, это характеристики эксплуатируемых потенциально опасных объектов и процессов: степень вероятности их выхода из-под контроля, параметры причиняемого при этом вреда (тяжесть, масштабы). Во-вторых, это уровень развития всевозможных технических средств и организационных мер, обеспечивающих удержание источника повышенной опасности под контролем, предвосхищающих ошибки тех, кто эти источники эксплуатирует, снижающих тяжесть или масштабы возможных последствий. Сюда же относятся специальные правила и требования безопасности.

В свою очередь, охранительные правовые нормы, закреплённые в трудовом, административном, а также уголовном законодательстве, оказываются третьей составляющей взаимодействия. Они не обеспечивают непосредственную защиту жизни и здоровья граждан, имущества, а являются стимулами, заставляющими граждан быть внимательными и предусмотрительными, постоянно соблюдать технику безопасности в противовес любой другой мотивации. Уголовное законодательство в этих условиях оказывается последним и самым мощным аргументом.

Характер взаимодействия трёх условно выделенных нами факторов оставляет немало вопросов. В частности, технические решения, направленные на предотвращение общественно опасных последствий, постоянно развиваются, правила и требования безопасности совершенствуются, однако тема неосторожной преступности регулярно занимает лидирующие позиции среди проблем, обсуждаемых общественностью и правоведами. Возможно, это связано с появлением новых свойств источников повышенной опасности в условиях, когда масштабы их эксплуатации увеличиваются в арифметической прогрессии. Но почему тогда уголовно-правовые нормы ${ }^{1}$ во взаимодействии с технологическими и организационными решениями не дают коренного перелома в вопросах предупреждения преступлений, совершаемых по неосторожности? Получается, что необходимость в соответствующих

${ }^{1}$ в тм числе во взаимосвязи с административно-правовыми уголовно-правовых запретах не вызывает сомнений, однако нет ясности в том, способен ли уголовный закон составить паритет вредоносности источников повышенной опасности и несовершенству технических и организационно-правовых мер защиты. Если нет, то нужна ли вообще ответственность за неосторожные преступления, к какому полезному социальному результату она ведёт?

Полагаем, что охранительные правовые нормы нужны, однако в настоящее время функциональные возможности уголовного закона по защите общественных отношений от неосторожного причинения вреда требуют принципиального осмысления.

С одной стороны, уголовно-правовые нормы являются регуляторами поведения, входят в систему социальных норм. Но с другой стороны, уголовная статистика за последние 50 лет свидетельствует об отсутствии какого-либо влияния на неосторожную преступность. Тот же уровень преступлений против безопасности дорожного движения и эксплуатации транспортных средств имеет положительный тренд, невзирая на ужесточение ответственности ${ }^{2}$.

Не случайно в юридической литературе представлены разные точки зрения, в том числе и полярные: от бесполезности и нецелесообразности уголовной ответственности за неосторожные преступления, до важности таких положений уголовного закона, необходимости дальнейшего ужесточения ответственности, с отведением уголовному кодексу основной роли в удержании неосторожной преступности хотя бы на имеющемся уровне.

На наш взгляд, ответ необходимо искать не в такой полярной системе суждений. Следует обратиться к особенностям функций уголовного закона и специфике механизма правового регулирования посредством охранительных уголовно-правовых норм.

Функции уголовного закона в своём предметном выражении зависят от структуры, которая представлена юридическими конструкциями, используемыми в диспозициях и санкциях его статей. Корректировки текста УК и даже новые определения могут, тем не менее, не затрагивать юридических конструкций, а потому не изменять механизм правового регулирования и характер воздействия на общественные отношения, способствуя лишь более точному уяснению нормативных предписаний, лаконичности изложения нормативного материала и проч.

\footnotetext{
${ }^{2}$ См.: Лунеев В.В. Преступность ХХ века: мировые, региональные и российские тенденции. Изд. 2-е, перераб. и доп. - М.: Волтерс Клувер, 2005. С. $334,339-340$
} 
Изменение же юридических конструкций непременно оказывает влияние на систему права и зачастую свидетельствует об изменившихся представлениях законодателя о целях или способах правового регулирования конкретной сферы общественных отношений ${ }^{3}$.

Учение о юридических конструкциях зародилось чуть более ста лет назад и ещё находится в стадии развития. С появлением системного подхода в методологическим арсенале науки оно существенно обогатилось и в настоящее время позволяет проводить прикладные исследования, рассматривая юридические конструкции, с одной стороны, как средство юридической техники ${ }^{4}$, а с другой стороны - как модель, отражающую те общественные отношения, которые государство пытается урегулировать с помощью права, либо которые оно стремится вызвать к жизни посредством создания законодательства и правовых стимулов ${ }^{5}$.

С.С. Алексеев, рассматривая сущность и место юридических конструкций в системе права, отмечает, что они «представляют собой органический элемент собственного содержания права, его внутренней формы, рождаемый на первых порах спонтанно, в самой жизни, в практике в результате процесса типизации» ${ }^{6}$ В свою очередь, Л.Л. Кругликов предлагает рассматривать юридическую конструкцию в качестве такого средства юридической техники, которое представляет собой абстракцию, разновидность нормативной модели, отражающей сложное строение соответствующих ей явлений и призванной придавать праву внутреннюю форму, строение ${ }^{7}$.

Такие «архитектурные элементы» системы права, следовательно, позволяют обеспечить связь между социальными и правовыми явлениями, приспосабливать право к сложившимся общественным отноше-

${ }^{3}$ См: Жалинский А.Э. Уголовное право в ожидании перемен: теоретико-инструментальный анализ. 2-е изд., перераб. и доп. - М.: Проспект, 2009. С. 72 - 74; Лопашенко Н.А. Уголовная политика. - М.: Волтерс Клувер, 2009. С. 222 - 223;

${ }^{4}$ Иеринг Р. Юридическая техника/ Пер. с нем. - СПб., 1906. С. 63 - 75; Ушаков А.А. Очерки советской законодательной стилистики. - Пермь, 1967. С. 73; Черданцев А.Ф. Юридические конструкции, их роль в науке и практике// Правоведение. 1972. № 3. С. 12 - 14

${ }_{5}^{5}$ Черданцев А.Ф. Логико-языковые феномены в праве, юридической науке и практике. - Екатеринбург, 1993. С.131 - 133

${ }^{6}$ Алексеев С.С. Восхождение к праву. Поиски и решения. - М.: HOPMA, 2001. C. $280-281$

${ }^{7}$ Юридические конструкции и символы в уголовном праве/ Л.Л. Кругликов, О.Е. Спиридонова. - СПб.: Издательство «Юридический центр Пресс», 2005. С.65 ниям и управлять последними, корректировать их в необходимых пределах через созданный механизм правового регулирования.

Учитывая эти функциональные особенности юридических конструкций и их двойственную природу (отражение сложившейся социальной практики и модель желаемого состояния объекта), К.К. Панько предлагает, хотя и с определённой долей условности, разделять юридические конструкции «на возникшие в праве спонтанно в процессе саморазвития, обусловленного требованиями жизненных ситуаций, вызванных тенденциями саморегуляции в обществе, и юридические конструкции, обусловленные развитием права по воле государственной власти и, естественно, искусственно созданные законоведами. Между ними также нет грани, которая бы резко отделяла одну от другой, поскольку оба вида конструкций закреплены в нормах права и разрабатываются юридической наукой» ${ }^{8}$.

Например, структуру состава преступления на уровне признаков можно рассматривать как логическую юридическую конструкцию. «Представляя собой единство элементов и признаков, конструкция состава преступления на уровне признаков содержит характеристику преступного деяния в логико-гносеологическом отношении» 9

Конкретный текст нормы уголовного закона формируется в процессе законотворчества с помощью определённых словоформ и разработанных наукой категорий. Таким образом юридическая конструкция наполняется конкретным семантическим содержанием.

В результате, несмотря на уникальность каждой нормы уголовного закона или каждой её редакции (прежней, новой), её текст описывает модель общественного отношения или поведенческого акта по заданным правилам, выработанным на тот момент наукой. В основном используются типовые конструкции. Соответственно, каждый вид конструкции имеет свои функциональные особенности, обнаруживаемые в процессе реализации готовых правовых норм.

При этом следует брать во внимание конструкции не только диспозиций, но и санкций охранительных норм уголовного закона, их модель ${ }^{10}$, поскольку санкция сама конструируется на базе системы на-

${ }^{8}$ Панько К.К. Юридические конструкции как категории внутренней формы (структуры) уголовного права// Право и политика. 2005. № 3. C. $20-21$

${ }^{9}$ Панько К.К. Указ. Соч. С.25

${ }^{10}$ Наумов А.В. Форма уголовного закона и ее социальная обусловленность// Проблемы совершенствования уголовного законодательства. - М., 1984. С. 19 


\section{Право и политика 4 (172) 2014}

казаний, а также определяет пределы наказуемости, концепцию уголовной репрессии в заданной сфере общественных отношений и особенности дифференциации уголовной ответственности ${ }^{11}$.

Очевидно, что составы преступлений, совершаемых по неосторожности, являются социально обусловленными. Тем не менее, они основаны не на таких юридических конструкциях, которые возникли благодаря саморазвитию, а на искусственных, разрабатываемых ради приведения общественных отношений в желаемое состояние (безопасное).

Разработка таких юридических конструкций является непростой задачей. Основная сложность состоит в выявлении действительного содержания тех форм общественных отношений, которые причиняют вред и должны выбраковываться из социальной практики путём их запрета. Если юридическая конструкция им не соответствует, она будет обладать слабыми охранительно-регулятивными свойствами, и задачи уголовного законодательства не будут выполняться надлежащим образом.

Что необходимо брать во внимание при анализе юридической конструкции? К числу наиболее важных свойств следует, на наш взгля, отнести смысловой фокус запрета, социально-психологические установки, которые связаны с запрещаемыми моделями поведения и подлежат выбраковыванию, а также особенности дифференциации уголовной ответственности (основание, количество ступеней, изменение параметров наказуемости).

Анализ отечественного уголовного законодательства позволяет обнаружить, что большинство статей о неосторожных преступлениях построено на базе одной юридической конструкции с некоторыми техникоюридическими вариациями. Этой конструкции более 40 лет и обладает она следующими особенностями. Во-первых, смысловая нагрузка ориентирована на запрете причинять тяжкий вред здоровью, смерть одному человеку, а также смерть двум или более лицам в результате нарушения различных правил и требований безопасности. Во-вторых, в основание дифференциации ответственности положены качественно-количественные характеристики общественно опасных последствий. Соответственно, получаем разные части статей с последствием в виде тяжкого вреда здоровью и в виде смерти (с разным количеством погибших). В третьих, используется опосредованная причинная связь.

\footnotetext{
${ }^{11}$ См.: Юридические конструкции и символы в уголовном праве/ Л.Л. Кругликов, О.Е. Спиридонова. - СПб.: Изд-во «Юридический центр Пресс», 2005. С.129-130
}

B-четвёртых, форма вины - неосторожная, в любом виде. В-пятых, адресат запрета (субъект) в большинстве случаев - лицо, обязанное соблюдать правила или требования безопасности, ответственное за эксплуатацию источника повышенной опасности.

В настоящее время описанная конструкция встречается в ст.ст. $143,215.1,216,217,217.1,219,264,263$, 263.1, 266, 267, 268, 269 УК РФ, некоторые отличия в дифференциации уголовной ответственности обнаруживаются в конструкциях ст.ст. 218, 217.2, 271.1, 215 УК РФ, а также в ч.ч. 2 и 3 ст.ст. 215.2 и 215.3 УК РФ $\Phi^{12}$, а потому заслуживают отдельного внимания.

Юридическая конструкция неосторожного преступления, описанная выше, несмотря на свою распространённость как раз и не даёт положительного социального результата. Тому есть несколько причин. Рассматриваемая нами юридическая конструкция неосторожного преступления дифференцирует ответственность по неосторожным последствиям, но предполагает не прямую и непосредственную причинно-следственную связь, а опосредованную, состоящую из нескольких звеньев.

С одной стороны это позволяет охватить юридической конструкцией механизм образования последствий при высоких показателях разброса вероятностей, когда причинная связь прокладывает свой путь в конкретном случае по уникальному сочетанию ситуативных факторов. Заранее предусмотреть такие факторы, а тем более описать их в законе очень сложно.

С другой стороны, эта же конструкция ставит правовую оценку содеянного в зависимость не от особенностей совершенного действия (бездействия). Квалификация содеянного зависит от того, как будет развиваться та самая многофакторная причинная связь и к каким конкретным уникальным последствиям она приведёт.

Современная наука не может однозначно ответить на вопрос о том, какие виды нарушений к каким конкретно последствиям строго и закономерно ведут, поскольку в этой системе отношений представлены зависимости не динамические, а статистические. Конкретный исход определяется случайными факторами, которые были вовлечены во взаимодействие в конкретном случае: исправностью/неисправностью пассивных систем безопасности, особенностями поведения потерпевшего и параметрами его здоровья,

\footnotetext{
${ }^{12}$ Следует упомянуть ст.ст. 109, 118, 168 и 224 УК РФ, а также экологические преступления, юридические конструкции в которых существенно отличаются. Они требуют самостоятельного рассмотрения, а потому в настоящей статье речь о них не идёт
} 
живучестью, прошедшим временем до начала оказания медицинской помощи, квалификацией медицинского персонала и т.д.

Ставить в вину то обстоятельство, что своим нарушением виновный вообще запустил такой механизм причинения вреда, нужно. Но как только мы дифференцируем уголовную ответственность в статьях Особенной части УК РФ по параметрам конечных последствий, так сразу мы заменяем многофакторную вероятностную их связь с деянием, существующую в реальной действительности, на другую - причинно-следственную, характерную для динамических закономерностей.

Здесь уместно возразить: соотношение философских категорий общего, особенного и единичного позволяет нам заявлять, что в каждом конкретном случае развитие такой связи носит одновременно и уникальный, и необходимый характер. Между тем, юридическая конструкция является категорией общего, отчего и носит нормативный характер. Следовательно, она не должна подменять собой единичное, т.е. конкретное уникальное явление социальной действительности.

Но является ли описанная особенность юридической конструкции неосторожного причинения вреда таким уж серьёзным недостатком? Для ответа на этот вопрос необходимо обратиться к обобщённым характеристикам правоприменительной практики и соотнести её с особенностями общественного и индивидуального сознания в регулируемых сферах общественных отношений.

Рассматриваемая нами юридическая конструкция обладает хорошей применимостью к конкретным случаям, поскольку позволяет обосновать юридическую ответственность при весьма сложных сочетаниях факторов в развитии причинной связи. Более того, судебная практика рассматривает связь между нарушениями правил безопасности и наступлением конкретных общественно опасных последствий не просто как опосредованную причинную, а как условную. При таком подходе действие (бездействие) может оказаться одним из нескольких необходимых условий наступления результата, без которого скорее всего такого исхода не было бы (т.н. conditio sine qua non).

Яркий пример приводит И. Я. Козаченко, рассматривая решение Военной коллегии Верховного Суда СССР, которым было отменено кассационное определение и оставлен в силе приговор суда первой инстанции о признании К. виновным в дорожно-транспортном преступлении. Подсудимый управлял грузовиком, в кузове которого находился другой гражданин. В процессе движения водитель не справился с управлением из-за гололеда, автомобиль стал резко менять траекторию движения, после чего столкнулся с деревьями. Пассажир, находившийся до этого в кузове, был обнаружен на проезжей части мертвым, смерть его наступила в том числе от падения на проезжую часть. В ходе расследования и судебного разбирательства не было достоверно установлено, что он выпал на ходу из-за нарушения правил дорожного движения, допущенного водителем. Была высока вероятность, что потерпевший сам выпрыгнул из автомобиля, когда водитель потерял управление, а если бы потерпевший оставался в кузове, то он бы не погиб. Заметим, что все неустранимые сомнения толкуются в пользу обвиняемого, а потому кассационная инстанция отменила обвинительный приговор. Принимая во внимание все названные обстоятельства, Военная коллегия Верховного Суда СССР тем не менее постановила, что подобное поведение потерпевшего стало возможным вследствие нарушения водителем правил дорожного движения и потери управления автомобилем, а потому причинная связь в уголовно-правовом смысле присутствовала ${ }^{13}$.

В приведённом примере нарушение правил дорожного движения, допущенное водителем, является как раз не причиной, а лишь одним из условий, без которого остальные факторы, взаимодействуя, скорее всего не привели бы к гибели пассажира. Как видим, существующая юридическая конструкция неосторожных преступлений позволяет во всех таких случаях устанавливать юридически значимую связь между нарушением правил или требований безопасности и конкретным результатом, позволяя привлекать виновных к уголовной ответственности.

Но существует и другая сторона этого явления. Хорошая применимость статей уголовного закона о неосторожных преступлениях очень слабо влияет на поведение граждан, взятое в массе. Об этом убедительно свидетельствует уголовная статистика. Дело в том, что в общественном сознании (и даже в индивидуальном) связь между нарушением определённых правил и наступлением общественно опасных последствий представлена не в уголовно-правовом смысле, а сформирована опытным путём.

Например, в 2012 году в России выявлено 64960311 нарушений правил дорожного движения и эксплуата-

\footnotetext{
${ }^{13}$ Проблемы причины и причинной связи в институтах Общей и Особенной частей уголовного права: вопросы теории, оперативно-следственной и судебной практики/ И.Я. Козаченко, В.Н. Курченко, Я.М. Злоченко. - СПб.: Изд-во «Юридический центр Пресс», 2003. С. $46-47$
} 


\section{Право и политика 4 (172) 2014}

ции транспортных средств ${ }^{14}$. За этот же период времени зарегистрировано 203597 дорожно-транспортных происшествий, в которых участники дорожного движения погибли либо получили любые травмы, не приведшие к смерти $^{15}$. В том же году было зарегистрировано 29370 преступлений против безопасности дорожного движения и эксплуатации транспорта, т.е. потерпевшим причинён тяжкий вред здоровью либо смерть ${ }^{16}$. Даже если не учитывать огромную латентность правонарушений, которые в итоге не привели к транспортным происшествиям и не были выявлены, получаем, что на одно неосторожное преступление пришлось 2211 правонарушений. Результаты контрольно-надзорной деятельности органов государственной власти и местного самоуправления свидетельствуют о том, что нарушения правил охраны труда, правил пожарной безопасности, правил ведения горных и строительных работ также очень распространены.

Следовательно, опыт относительно безболезненного нарушения всевозможных правил позволяет гражданам считать вероятность наступления общественно опасных последствий от своего поведения столь небольшой, что она близка именно случайной. Эмпирическое подтверждение этих выводов можно встретить в специальной литературе ${ }^{17}$. Неудивительно поэтому, что убеждения граждан о недопустимости причинения вреда другим лицам, их нежелание такого исхода, а также отношение к себе как к вполне полезным представителям общества уживаются с распространённой практикой всевозможных, регулярно допускаемых нарушений требований безопасности.

\footnotetext{
${ }^{14}$ Сведения за 2012 год. Количество дорожно-транспортных происшествий // Госавтоинспекция МВД России [Электронный pecypc] : URL : http://www.gibdd.ru/upload/iblock/8b0/8b011aafbed dbed188f8ec3c61309264.xls (Режим доступа: Microsoft Excel; Дата обращения - 27.02.2014 г.)

${ }^{15}$ Сведения за 2012 год. Количество административных правонарушений в области безопасности дорожного движения // Госавтоинспекция МВД России [Электронный ресурс] : URL : http:// www.gibdd.ru/upload/iblock/d9a/d9a15216b5bc396057f72e137ac ff074.pdf (Режим доступа: Adobe Acrobat Reader; Дата обращения -27.02 .2014 г.)

${ }^{16}$ Состояние преступности - январь - декабрь 2012 года. Статистика и аналитика // МBД России [Электронный ресурс] : URL : http://mvd.ru/upload/site1/document_file/vlXMMRlab8.pdf (Режим доступа: Adobe Acrobat Reader; Дата обращения - 27.02.2014 г.)

17 Лунеев В.В. Преступность ХХ века: мировые, региональные и российские тенденции. Изд. 2-е, перераб. и доп. - М.: Волтерс Клувер, 2005. С. 336 - 341; Дорожно-транспортная преступность: закономерности, причины, социальный контроль/ А.Ю. Кравцов, А.И. Сирохин, Р.В. Скоморохов, В.Н. Шиханов, под ред. В.В. Лунеева. - СПб.: Изд-во «Юридический центр Пресс», 2011. С. 269 - 289
}

Сюда же следует добавить состояние аномии, возникающее во многих сферах жизнедеятельности, когда сложные правила или требования техники безопасности не позволяют увеличить выработку, получить больше прибыли, как того требует работодатель или общее содержание культуры нашего капиталистического общества, система его ценностей.

И хотя на уровне обобщений мы обнаруживаем устойчивые статистические зависимости между нарушениями правил и наступлением вредных последствий, тем не менее в представлениях граждан и на примере конкретных случаев общественно опасный результат выглядит скорее как исключение из сложившейся социальной практики. Параметры конечного результата (сколько человек получило тяжкий вред здоровью, сколько погибло) тем более оказываются случайными, однако правовая оценка допущенных нарушений оказывается жёстко детерминированной конкретными видами последствий.

Следовательно, чем дробнее дифференциация уголовной ответственности по признакам характеристики неосторожных последствий (с условной связью), тем больше уголовно-правовая оценка одних и тех же нарушений зависит от уникальности неуправляемых и вероятностных многофакторных причинных связей в каждом случае, а потому напоминает ордалий. Насколько это пригодно для уголовной юстиции? Если преследовать цели возмездия за конкретные виды причинённого вреда, то в какой-то степени это допустимо. Однако для правового регулирования такой подход не годится, поскольку большинству граждан полученный общественно опасный результат, а также вызванная им правовая оценка кажутся случайными и на собственный опыт не экстраполируются. Если бы это было не так, то при существующей судебной практике случаи осознанного нарушения правил или требований безопасности уже стали бы редкостью.

Нельзя обойти вниманием и другое обстоятельство. Поскольку в статьях УК РФ о неосторожных преступлениях основная смысловая нагрузка ориентирована на общественно опасные последствия допущенных нарушений, постольку объективная сторона предполагает любые нарушения, стоящие в причинной связи с вредным результатом. Это может показаться логичным техникоюридическим решением. К тому же оно в некотором смысле облегчает работу по квалификации содеянного, хотя и обладает некоторыми побочными эффектами.

Так, в приговорах судов легко обнаружить практику перечисления всех выявленных нарушений специальных правил или требований безопасности, которые 
предшествовали наступлению вредного результата. Например, водитель управлял транспортным средством, оставив дома документы или не имея доверенности на управление данным транспортным средством, не был сам пристёгнут, не было в автомашине огнетушителя, он не учитывал особенностей дорожного покрытия, видимости и т.д., и в итоге при обнаружении опасности для движения в виде пешехода на дороге не принял мер к снижению скорости вплоть до полной остановки транспортного средства, как того требует п.10.1 Правил дорожного движения, а совершил манёвр, выехал на встречную сторону и допустил столкновение с другим автомобилем, в котором погиб пассажир, не пристегнувшийся ремнём безопасности ${ }^{18}$.

Вместе с тем, не все нарушения специальных правил и требований безопасности в реальной действительности ведут к наступлению общественно опасных последствий, т.е. разные нарушения обладают разным потенциалом в этом отношении. Это легко обнаружить путём обобщения той же судебной практики, если критично относиться к причинной связи и не брать во внимание те нарушения, которые излишне вменяются в вину по объективной стороне. Но можно ли понять из текста уголовного закона, какие именно отступления от правил и требований безопасности он подразумевает среди огромного количества возможных?

Такие нарушения оказываются обезличенными и, говоря терминами дискурс-анализа и лингвистической концепции «упаковки», не входят в фокус уголовно-правового запрета ${ }^{19}$. Это вызвано в том числе и обратным порядком слов, поскольку в диспозициях статей УК РФ о неосторожных преступлениях вместо канонического порядка слов используется причастный оборот: «нарушение правил, повлекшее по неосторожности причинение ...».

Между тем, информационная, смысловая составляющая уголовно-правовых запретов является одной из важных сторон социального контроля. Запрещённая

\footnotetext{
${ }^{18}$ Например, Приговор Медногорского городского суда Оренбургской области в отношении Рябова М.С. от 24.01.2012 г.// РосПравосудие [Электронный ресурс] : URL : https://rospravosudie.com/courtmednogorskij-gorodskoj-sud-orenburgskaya-oblast-s/act-101318346/ (Дата обращения: 27.02.2014 г.); Приговор Большесосновского районного суда Пермского края в отношении Кутузова А.М. от 24.01.2014 г. // Судебные решения. РФ [Электронный ресурс] : URL : http://xn--90afdbaav0bd1afy6eub5d.xn--plai/bsr/case/6523157 (Дата обращения - 27.02.2014 г.) и нек. др.

${ }^{19} \mathrm{O}$ дискурсивном анализе, коммуникативной онтологии и антропоцентрическом подходе в исследованию юридических текстов см.: Ситникова А.И. Законодательная текстология уголовного права: монография. - М.: Юрлитинформ, 2011. С. 33 - 40
}

модель поведения транслируется гражданам с помощью совокупности знаков в форме стереотипа ${ }^{20}$, а потому важное значение приобретает репрезентация. Она определяет в сообщении место каждого из связанных явлений, создаёт тот самый смысловой фокус. В нашем случае выходит, что УК РФ запрещает не столько нарушать правила, сколько допускать конкретные виды общественно опасных последствий - в фокусе находится соответствующий иконический знак, который вызывает эмоционально окрашенный чувственный образ (смерть, вред здоровью). Этого не скажешь о презентации нарушения - оно оттесняется на задний план, становится фоном.

Каким образом это сообщение взаимодействует с представлениями граждан, с их правосознанием? Оно соотносится с опытом, который, в свою очередь, содержит сформировавшееся представление: вероятность наступления последствий, оказавшихся в фокусе сообщаемого уголовно-правового запрета, видится очень низкой в противовес частоте допускаемых нарушений правил и требований безопасности. Соответственно, в сознании граждан зачастую не сформировано строгих причинных зависимостей между определёнными нарушениями правил и конкретными разновидностями последствий. В итоге сообщённому запрету о неосторожном преступлении отводится роль одного из многих предостережений из разряда крайних форм неудач, о которых нам говорят с детства и которые нас, как мы надеемся, обойдут стороной.

В таких условиях слабый общепредупредительный потенциал у статей УК РФ о неосторожных преступлениях - явление закономерное, при любых видах наказаний, которыми они угрожают. Н.Кристи также обращал внимание на эту особенность уголовного законодательства, хотя и объяснял её иначе: «некоторые из нас не настолько умны, чтобы учиться на опыте других людей». ${ }^{21}$

Заметим, что юридические конструкции, используемые в УК РФ, не учитывают тех особенностей социальной практики и общественного сознания, о которых было сказано выше. Можно ли считать, что они являются отражением тех общественных отношений, для урегулирования которых созданы? На наш взгляд ответ является отрицательным.

Заслуживает внимания и другая особенность юридической конструкции неосторожных преступлений,

\footnotetext{
${ }^{20}$ См. об этом: Антонов А.Д. Теоретические основы криминализации и декриминализации : Дис... канд. юрид. наук: 12.00.08. - М.: МГУ им. М.В. Ломоносова, 2001. С. $35-37$

${ }^{21}$ Кристи Н. Пределы наказания / Под. ред. З.И. Луковникова. М.: Прогресс, 1984. С. 22
} 


\section{Право и политика 4 (172) $\bullet 2014$}

используемой в УК РФ: она нечувствительна к видам неосторожной вины. В правоприменительной практике по делам о нарушении специальных правил и требований безопасности это привело к возникновению двух правовых явлений. Во-первых, судебно-следственной практикой созданы гибридные виды неосторожности, а во-вторых, по некоторым видам неосторожных преступлений закон применяется по правилам объективного вменения - вина не устанавливается, а заменяется фактом наступления общественно-опасных последствий. Последнее правило напоминает строгую ответственность в странах англо-саксонской правовой семьи (actus reus), когда для привлечения к ответственности достаточно совершения материальных действий (объективной стороны) $)^{22}$.

Так, в 89,5\% изученных приговоров о нарушении правил дорожного движения и эксплуатации транспортных средств (период выборки - с 2006 по 2014 г.г.) преимущественно описывается объективная сторона содеянного (какие обязанности на виновного были возложены, что он обязан знать и соблюдать, какие нарушения допустил, каков механизм дорожно-транспортного происшествия, как развивалась причинная связь и каковы общественно опасные последствия). Вина в лучшем случае обозначены без анализа содержания.

В 47,4\% приговоров для описания субъективной стороны используются практически шаблонные формулировки, построенные по определённой схеме: подсудимый, будучи обязанным знать и соблюдать относящиеся к нему требования правил, которые он легкомысленно проигнорировал, надеясь на благополучный исход, в ходе движения проявил грубую самонадеянность и невнимательность, при возникновении опасности для движения (в виде пешехода или другого автомобиля), которую он имел возможность и был обязан своевременно обнаружить, и далее - идёт описание того, что конкретно подсудимый сделал, обеспечив наезд, столкновение, опрокидывание (например, применил маневр влево, не обеспечив его безопасность).

Другая схема: подсудимый проявил преступное легкомыслие и невнимательность к дорожной обстановке и её изменениям, выразившиеся в том, что будучи обязанным знать и соблюдать относящиеся к нему требования Правил дорожного движения РФ (перечисляются) и действовать таким образом, чтобы не создавать опасности и не причинять вреда другим участникам движения, и далее - снова описание кон-

\footnotetext{
${ }^{22}$ См.: Есаков Г.А. Mens rea в уголовном праве США: историкоправовое исследование/ Предисл. О.Ф. Шишова. - СПб.: Изд-во «Юридический центр Пресс», 2003. С. $297-298$
}

кретных действий или бездействия, которые привели к общественно опасным последствиям ${ }^{23}$.

Нельзя не заметить, что во всех таких случаях органы расследования и суд так и не приходят к выводу: совершено ли преступление по легкомыслию, либо по небрежности. На самом деле этот вопрос принципиально важен, поскольку названные разновидности неосторожной вины являются взаимоисключающими ввиду специфических признаков психического отношения к деянию и его общественно опасным последствиям. Из текста таких приговоров видно, что ни один из видов неосторожной вины в полной мере не описан: не хватает важных признаков как для легкомыслия, так и для небрежности. При этом уголовный закон не предусматривает и вариантов какой-либо субсидиарной вины, когда недостающие признаки психического отношения одного вида можно заменить иными признаками (несколькими) из вины принципиально другого вида.

Следовательно, правоприменительная практика, использующая гибридные виды неосторожной вины, балансирует на грани законности. Но если сложившийся подход ещё можно списать на недостатки юридической техники индивидуальных правовых актов, то практика квалификации по ст. 143 УК РФ (о нарушении требований охраны труда) заслуживает резкой критики.

В изученных нами приговорах субъективное отношение виновных к содеянному вовсе не обсуждалось. Схема утверждения о наличии состава преступления построена на перечислении положений нормативных правовых актов, регламентирующих вопросы организации и обеспечения безопасности работников при производстве работ определённого вида. Затем описываются допущенные нарушения, механизм происшествия и наступившие общественно опасные последствия (с описанием причинной связи). После этого суды констатируют: подсудимый, таким образом, нарушил правила (требования) охраны труда, что повлекло по неосторожности такие-то последствия. Вопреки правилам логики вывод о неосторожной вине в этих случаях вытекает из констатации запрещённых материальных действий с их результатом. Максимум, что можно здесь усмотреть - это отсутствие умысла у подсудимого на

\footnotetext{
${ }^{23}$ Например: Приговор Кропоткинского городского суда Краснодарского края в отношении Андриец И.С. от 19.02.2014 г. // Судебные решения. РФ [Электронный ресурс] : URL : http:// xn--90afdbaav0bd1afy6eub5d.xn--p1ai/bsr/case/6546910 (Дата обращения - 10.03.2014 г.); Приговор Усть-Илимского городского суда Иркутской области в отношении Поддубнова М.П. от 30.04.2013 г. // РосПравосудие [Электронный ресурс] : URL : https://rospravosudie.com/court-ust-ilimskij-gorodskoj-sud-irkutskayaoblast-s/act-107324450/ и др.
} 
причинение вреда пострадавшим работникам. Вместе с тем, отсутствие умысла ещё не означает наличия неосторожности, и сама эта форма вины требует проверки с выбором одной из двух разновидностей.

Эта практика, вне всяких сомнений, является объективным вменением. Подобный подход обнаружен нами в 40,7 \% приговоров по делам о дорожно-транспортных преступлениях. Наверное, во всех этих случаях нарушения специальных правил или требований безопасности при тщательном анализе материалов дела можно установить конкретный вид неосторожной вины. Тем не менее, суды этому вопросу не уделяют никакого внимания.

Здесь мы сталкиваемся с проблематикой баланса между интересами применимости статей уголовного закона о неосторожных преступлениях и интересами уголовно-правового регулирования. При всей кажущейся близости этих интересов, между ними существуют различия.

В специальной литературе неоднократно обращалось внимание на то, что охранительная уголовно-правовая норма в системе социального контроля должна обозначать не столько запрещаемые действия, бездействие и последствия, сколько социально-психологические установки, мотивацию и систему ценностей, которые приводят к запрещаемым моделям поведения.

С этим связана дифференциация уголовной ответственности по формам вины: иначе в чём была бы разница между случаями причинения смерти другому человеку, описанными сейчас в ст.ст. 105 и 109 УК РФ? С этим же связан выбор большинства квалифицирующих признаков в тексте уголовного закона и требования об их осознании виновным ${ }^{24}$. С другой стороны это осложняет квалификацию и процесс доказывания. Однако обратимся к истории вопроса: уголовное законодательство вслед за развитием гуманитарных и общественных наук не упрощалось, а напротив, усложнялось и всё

\footnotetext{
${ }^{24}$ Следует здесь обратить внимание на позицию Верховного Суда РФ по делам об изнасилованиях и насильственных действиях сексуального характера о необходимости осознания несовершеннолетия и малолетства потерпевшей несовершеннолетней, хотя из текста уголовного закона был исключён признак заведомости по отношению к возрасту жертвы. См.: О внесении изменения в постановление Пленума Верховного Суда Российской Федерации от 15 июня 2004 года № 11 «О судебной практике по делам о преступлениях, предусмотренных статьями 131 и 132 Уголовного кодекса Российской Федерации»: постановление Пленума Верховного Суда Российской Федерации от 14.06.2013 г. № 18// Верховный Суд Российской Федерации [Электронный ресурc] : URL : http://www. supcourt.ru/Show_pdf.php?Id=8709 (Дата обращения -25.02 .2014$ г.); Определение Судебной коллегии по уголовным делам Верховного Суда Российской Федерации от 31.01.2011 г. № 3-О11-2 // Бюллетень Верховного Суда Российской Федерации. 2011. № 8
}

большее внимание уделяло субъективной стороне. Следовательно, простота доказывания (и в целом применения уголовно-правовой нормы) ещё не несёт в себе положительного потенциала и не обеспечивает нужного социального эффекта.

Поскольку право призвано управлять поведением людей, воздействовать на их сознание и волю, постольку бессмысленно дифференцировать ответственность по признакам непроизвольных единиц поведения (например, рефлекторным реакциям) либо по таким признакам, которые не связаны с поведением человека или же находятся в отдалённых связях с ним. Именно такие методологические позиции прослеживаются в работах Л.Л. Кругликова. К основанию межотраслевой дифференциации ответственности он относит характер вредоносности соответствующего вида поведения, а к признакам, которые могут использоваться в качестве критерия степени отклонения от нормы должно-дозволенного, он относит либо характеристики деяния, либо одновременно и деяния и самого деятеля ${ }^{25}$.

Таким образом, требования ясно обозначать нежелательные типы социально-психологической установки или мотивации поведения при конструировании правовых норм - залог эффективного правового регулирования посредством охранительной функции права. Соответствует ли этому требованию применяемая в УК РФ юридическая конструкция неосторожного преступления? Очевидно, что нет: уголовный закон не дифференцирует столь разные модели поведения, которые с субъективной стороны могут быть описаны либо как легкомысленные, либо как небрежные. Если привести юридические конструкции в соответствие с упомянутым требованием и дифференцировать ответственность по разным видам неосторожности, это позволит обратить внимание судов на необходимость точного установления вида неосторожной вины, а также сделать уголовно-правовые запреты более удачными методологически.

Отдельного внимания заслуживают юридические конструкции санкций для неосторожных преступлений. В частях статей Особенной части УК РФ о квалифицированных и особо квалифицированных видах преступления они по своему содержанию являются преимущественно возмездными, поскольку содержат только наказания, связанные с ограничением личной свободы. При этом особо квалифицированные виды неосторожных преступлений, относясь к категории

\footnotetext{
${ }^{25}$ Дифференциация ответственности в уголовном праве/ Л.Л. Кругликов, А.В. Васильевский. - СПб.: Юридический Центр Пресс, 2003. C.52, 181
} 


\section{Право и политика 4 (172) • 2014}

преступлений средней тяжести, предусматривают достаточно длительные сроки лишения свободы (варианты срока: 5, 7, 9 или 10 лет). В качестве дополнительного факультативного наказания в преступлениях со специальным субъектом предусмотрено лишение права занимать определённые должности или заниматься определённой деятельностью на срок до трёх лет.

Целевые характеристики таких конструкций также требуют принципиального обсуждения. Например, Я. И. Гилинский отмечает, что результаты современных исследований нарушают некоторые представления о причинах неосторожной преступности и конкретных преступлений, а потому ставят под сомнение целесообразность и эффективность существующих мер уголовного наказания за их совершение: «да, всегда надо быть внимательнее, осторожнее, осмотрительнее, предусмотрительнее, но надо ли для этого сажать в тюрьму?» ${ }^{26}$.

Действительно, если преступление совершается по небрежности, а причинно-следственные связи носят опосредованный многофакторный характер, то почему при гибели двух человек виновному требуется больше времени на исправление, чем в случаях гибели только одного потерпевшего? И действительно ли на привитие внимательности и предусмотрительности нужно семь, а то и десять лет лишения свободы?

Очевидно, что весьма большие сроки наказаний в виде принудительных работ, ограничения свободы и лишения свободы в санкциях о неосторожных преступлениях преследуют не цели исправления, а цели восстановления социальной справедливости и общей превенции.

Однако в этом состоит одна из фундаментальных проблем используемых юридических конструкций и вообще современного подхода к пенализации в рамках уголовной политики. Обобщение судебной статистики, а также анализ приговоров по делам о неосторожных преступлениях позволяет обнаружить серьёзные расхождения между представлениями законодателей об общественной опасности неосторожных преступлений с одной стороны и убеждениями правоприменителей с другой стороны.

Как результат: суды не находят оснований для назначения строгих наказаний, которые предусмотрены статьями Особенной части УК РФ о неосторожных преступлениях. При этом далеко не всегда можно назна-

${ }^{26}$ Гилинский Я.И. Криминология: теория, история, эмпирическая база, социальный контроль, 2-е изд., перераб. и доп. - СПб.: Издательство Р. Асланова «Юридический центр Пресс», 2009. С.374 чить наказание по правилам ст. 64 УК РФ. Как результат - более $2 / 3$ назначаемых наказаний постановляется считать условными. Столь распространённая практика применения положений ст. 73 УК РФ свидетельствует об отсутствии у судов надлежащих инструментов уголовно-правового воздействия в отношении конкретных нарушителей. Несомненно, в ряде случаев исправление виновного целесообразно сочетать с его изоляцией в условиях колонии-поселения или исправительной колонии общего режима (поскольку принудительные работы до сих пор не применяются), однако в распоряжении суда должны быть меры, рассчитанные не только на крайний случай.

С другой стороны было бы неправильным считать, что высокий уровень и нежелательные тенденции неосторожной преступности вызваны тем, что граждане не знают об уголовной ответственности или же не боятся мер, предусмотренных законом. Кафедрой уголовноправовых дисциплин и студентами Иркутского юридического института (филиала) Академии Генеральной прокуратуры Российской Федерации летом 2013 года в г. Иркутске был проведён опрос 320 граждан, в выборку вошли мужчины и женщины как управляющие, так и не управляющие транспортными средствами. Возраст опрашиваемых составил от 17 до 71 года.

Респондентам были заданы два вопроса: какая, по их мнению, ответственность грозит в настоящее время за грубое нарушение Правил дорожного движения, в результате которого произойдет ДТП и серьезно пострадают люди (попадут в реанимацию, станут инвалидами). Вторая ситуация повторяла первую, но была дополнена условием: если виновный водитель будет находиться в состоянии алкогольного опьянения. Данные вопросы имитировали диспозиции ч. 1 и ч. 2 ст. 264 УК РФ, предусматривающие ответственность за причинение тяжкого вреда здоровью по неосторожности в сфере дорожного движения и эксплуатации транспортных средств.

Обобщённое мнение респондентов было сопоставлено с показателями судебной статистики о доле реального лишения свободы в общем числе назначенных наказаний по указанным частям ст. 264 УК РФ. Результаты показали, что граждане знают о вероятности наступления уголовной ответственности даже при отсутствии летального исхода, и боятся наказания. Более того, они полагают, что карательные последствия неосторожного преступного поведения гораздо суровее тех, которые фактически обнаруживаются судебной практикой: $65 \%$ респондентов убеждены, что водителя за автотранспортное преступление, подпадающее под 
признаки ч.1 ст. 264 УК РФ, направят в места лишения свободы. О практике условного осуждения заявило лишь 7\% по ситуации с трезвым водителем и 2\% - по водителю в состоянии опьянения.

Значит, гуманная судебная практика не оказывает пагубного влияния на общее правосознание граждан и не детерминирует их неправомерное поведение при эксплуатации источников повышенной опасности. Следовательно, и ресурс общей превенции уже исчерпан и большего эффекта, чем имеется сейчас, ждать от метода устрашения вряд ли следует.
Несомненно, их перечень целесообразно вынести за пределы текста уголовного закона, определив в отраслевых законах или подзаконных нормативных правовых актах федерального уровня. Перечень таких нарушений можно установить путём обобщения юридической практики. В него должны входить такие нарушения, которые непосредственно или в минимальном сочетании с другими традиционно ведут к выходу опасных процессов из-под контроля и причинению крупного ущерба, причинению тяжкого вреда здоровью другим лицам или их гибели.

Таблицุа №1

Сравнение показателей судебной статистики и мнения респондентов об ответственности за деяния, предусмотренные ч.ч. 1 и $2 \mathrm{~cm} .264$ УК РФ

\begin{tabular}{|c|c|c|c|c|}
\hline & \multirow{3}{*}{$\begin{array}{c}\text { Осуждено к } \\
\text { реальному лишению } \\
\text { (от всех приговоров } \\
\text { за 2009-2011 гг.) }\end{array}$} & \multicolumn{3}{|c|}{ Мнение респондентов } \\
\hline & & \multicolumn{2}{|c|}{ Уголовная ответственность наступит } & \multirow[b]{2}{*}{$\begin{array}{c}\text { Уголовная } \\
\text { ответственность не } \\
\text { наступит }\end{array}$} \\
\hline & & $\begin{array}{l}\text { В виде реального } \\
\text { лишения свободы }\end{array}$ & $\begin{array}{c}\text { Иное уголовное } \\
\text { наказание } \\
\text { (в т.ч. лишение } \\
\text { свободы условно) }\end{array}$ & \\
\hline ч. 1 ст.264 УК РФ & $7,8 \%$ & $65 \%$ & $26 \%(7 \%)$ & $9 \%$ \\
\hline ч.2 ст.264 УК РФ & $24 \%$ & $87 \%$ & $8 \%(2 \%)$ & $5 \%$ \\
\hline
\end{tabular}

Следует обратить внимание и на параметры дополнительного наказания в виде лишения права занимать определённые должности или заниматься определённой деятельностью. Не лишая виновного основных прав и свобод, это наказание, тем не менее, способно надолго отстранить невнимательных или излишне самонадеянных граждан от эксплуатации опасных объектов и процессов. Однако карательный потенциал дополнительного наказания в статьях УК РФ о неосторожных преступлениях не превышает уровня своих аналогов из Кодекса Российской Федерации об административных правонарушениях (ст.ст. 3.8 и 3.11 соответственно). С позиции межотраслевой дифференциации юридической ответственности это представляется неправильным.

В каком же направлении следует совершенствовать юридическую конструкцию неосторожного преступления? Учитывая высказанные замечания и параметры социальной практики, можно выделить шесть предложений.

Первое. Желательно выделить класс так называемых грубых нарушений правил и требований безопасности для каждой сферы общественных отношений (по соответствующим статьям Особенной части УК РФ).
При всей спорности этого предложения, оно способствует изменению «фокуса» уголовно-правового запрета. Кроме того, подобный небезуспешный опыт имеется в уголовном законодательстве зарубежных стран, когда уголовная ответственность устанавливается и вовсе за сам факт грубого нарушения правил безопасности, создающее угрозу гибели других людей (т.н. состав угрозы) ${ }^{27}$.

Второе. Необходимо отказаться от дробной дифференциации уголовной ответственности по количественно-качественным характеристикам неосторожных последствий. Возможно, имеет смысл делить их на две ступени: без смертельного исхода (куда войдут крупный ущерб, вред здоровью определённой степени тяжести любому количеству людей), а также со смертельным исходом (когда погиб хотя бы один человек). Более дробная дифференциация имеет смысл в общих нормах о неосторожном причинении вреда: в ст.ст. 109, 118 УК РФ.

\footnotetext{
${ }^{27}$ Ст. 332 Закона об уголовном праве Израиля; ст.ст. 1, 3, пар. 2 ст. 5а главы 13 Уголовного кодекса Швеции и др.
} 


\section{Право и политика 4 (172) • 2014}

Третье. Следует проводить дифференциацию ответственности по виду неосторожной вины. Ответственность за легкомысленное грубое нарушение определённых правил, если это повлекло названные в законе общественно опасные последствия, должна быть суровее, чем в случае небрежного причинения вреда.

Четвертое. Санкции статей о неосторожных преступлениях должны предусматривать больше альтернативных наказаний, чтобы суд смог назначить их реально, а не использовать исключения из общего правила (ст. ст. 64, 73 УК РФ).

Пятое. Санкции статей о неосторожных преступлениях должны предусматривать возможность длительного лишения права занимать определённые должности или заниматься определённой деятельностью. Здесь суд сможет ориентироваться на масштабы последствий и на вид неосторожной вины. Положения Общей части УК РФ уже в настоящее время позволяют определить верхний предел такого наказания на уровне и пятнадцати, и двадцати лет.

Шестое предложение является технико-юридическим, имеющим семиотическое значение. Следует скорректировать формулировку диспозиций в статьях о неосторожных преступлениях так, чтобы сместить смысловой фокус уголовно-правового запрета с последствий на связь их с деянием и его свойствами - грубым нарушением правил и требований безопасности. Для этого следует заменить причастный оборот «повлекшее ...» на придаточное предложение «если это повлекло .... $\rangle^{28}$.

Перечисленные выше предложения об изменении юридической конструкции неосторожного преступления позволят оставить сложные опосредованные причинные связи пригодными для уголовной ответственности, но ответственность будет в меньшей степени зависеть от уникальности ситуативных факторов, ведущих к конкретным общественно опасным последствиям. Кроме того, уголовный закон сфокусирует внимание на определённых типах социально-психологических установок и мотивации поведения, воздействуя этим и на общественное сознание. Одновременно правоприменители будут вынуждены точно определять вид неосторожной вины для правильной квалификации и назначения наказания. Это будет способствовать укреплению законности и достижению целей уголовного наказания.

Несомненно, проблему неосторожной преступности не способен снять ни один даже самый совершенный уголовный закон. Тем не менее, неизбирательная ответ-

${ }^{28}$ См. также о роли рестриктивных оговорок в конструкциях состава преступления: Ситникова А.И. Указ. Соч. С. 297 - 299, 301 ственность, похожая на практики ордалия, работающая на принципах объективного вменения сводит к нулю даже тот эффект социального контроля, который при данном уровне развития общества объективно возможен.

\section{Библиография:}

1. Алексеев, С. С. Восхождение к праву. Поиски и решения/ С. С. Алексеев. - М.: НОРМА, 2001. -752 с.

2. Антонов, А.Д. Теоретические основы криминализации и декриминализации : Дис... канд. юрид. наук : 12.00 .08 / А. Д. Антонов. - М.: МГУ им. М.В. Ломоносова, 2001. - 182 с.

3. Гилинский, Я. И. Криминология: теория, история, эмпирическая база, социальный контроль/ Я. И. Гилинский. - 2-е изд., перераб. и доп. СПб.: Издательство Р. Асланова «Юридический центр Пресс», 2009. - 504 с.

4. Дифференциация ответственности в уголовном праве/ Л. Л. Кругликов, А. В. Васильевский. - СПб.: Юридический Центр Пресс, 2003. - 298 с.

5. Дорожно-транспортная преступность: закономерности, причины, социальный контроль/ А.Ю. Кравцов, А.И. Сирохин, Р.В. Скоморохов, В.Н. Шиханов, под ред. В.В. Лунеева. - СПб.: Изд-во «Юридический центр Пресс», 2011. - 474 с.

6. Есаков, Г. А. Mens rea в уголовном праве США: историко-правовое исследование/ Г. А. Есаков, предисл. О.Ф. Шишова. - СПб.: Изд-во «Юридический центр Пресс», 2003. - 553 с.

7. Жалинский, А. Э. Уголовное право в ожидании перемен: теоретико-инструментальный анализ/ А. Э. Жалинский. - 2-е изд., перераб. и доп. - М.: Проспект, 2009. - 400 с.

8. Кристи, Н. Пределы наказания / Н. Кристи, пер. с англ. В.М. Когана, под. ред. З.И. Луковникова. - М.: Прогресс, 1985. - 198 с.

9. Лопашенко, Н. А. Уголовная политика/ Н. А. Лопашенко. - М.: Волтерс Клувер, 2009. - 608 с.

10. Лунеев, В. В. Преступность ХХ века: мировые, региональные и российские тенденции/ В. В. Лунеев. -Изд. 2-е, перераб. и доп. - М.: Волтерс Клувер, 2005. -912 с.

11. Наумов, А. В. Форма уголовного закона и ее социальная обусловленность/ А. В. Наумов, ИГПАН // Проблемы совершенствования уголовного законодательства. - М., 1984. - С. 18 - 27

12. Панько К.К. Юридические конструкции как категории внутренней формы (структуры) уголовного права// Право и политика. - 2005. - № 3. - С. 19 - 28 
13. Проблемы причины и причинной связи в институтах Общей и Особенной частей уголовного права: вопросы теории, оперативно-следственной и судебной практики/ И. Я. Козаченко, В. Н. Курченко, Я. М. Злоченко. - СПб.: Изд-во «Юридический центр Пресс», 2003. - 791 с.

14. Ситникова, А. И. Законодательная текстология уголовного права: монография/ А. И. Ситникова. - М.: Юрлитинформ, 2011. - 344 с.

15. Черданцев, А. Ф. Логико-языковые феномены в праве, юридической науке и практике/ А. Ф. Черданцев. - Екатеринбург, 1993. - 192 с.

16. Юридические конструкции и символы в уголовном праве/ Л. Л. Кругликов, О. Е. Спиридонова. - СПб.: Изд-во «Юридический центр Пресс», 2005. - 336 с

17. Ю.В. Козубенко Исследование механизма уголовно-правового регулирования на межотраслевом уровне // LEX RUSSICA (РУССКИЙ ЗАКОН). 2013. - 6. - C. 655-661.

18. А.И. Комаров, Т.В. Яровенко. Некоторые проблемы проверки версии причинения смерти из огнестрельного оружия по неосторожности // Право и политика. -2009 . - № 7.

19. М.Ф. Лукьяненко. «Добросовестность»: закон и практика применения. Часть вторая. Окончание // Право и политика. - 2009. - № 7.

20. М. Ф. Лукьяненко. «Добросовестность»: закон и практика применения. Часть $1 / /$ Право и политика. -2009 . - № 6.

21. В.А. Калиновский, А.И. Комаров. Проверка версии обвиняемой о причинении смерти по неосторожности. // Право и политика. - 2008. - № 8.

22. Алиев Назим Казим оглы. Некоторые вопросы совершенствования норм о понятии и признаках соучастия в уголовном законодательстве Азербайджана // Право и политика. - 2013. - № 2. - C. 104-107. DOI: 10.7256/1811-9018.2013.02.8.

23. Паньшин Д.Л.. Некоторые актуальные вопросы применения лишения права управления транспортными средствами за административные правонарушения в области дорожного движения // Административное и муниципальное право. - 2013. - № 10. - C. 104-107. DOI: 10.7256/19992807.2013.10.9112.

24. Баширова А.Ф., Истратов А.А.. Правовое регулирование профилактики дорожно-транспортного травматизма // Полицейская деятельность. - 2012. - № 2. - C. 104-107.

25. Москвина Ю.В.. О причинении материального ущерба в результате дорожно-транспортного происшествия как обстоятельстве, отягчающем административную ответственность // Административное и муниципальное право. - 2011. - № 11. - C. 104-107.

26. Борейко Ю.А.. Формирование системы учета административных правонарушений в области дорожного движения. // Полицейская деятельность. - 2011. - № 2. - С. 104-107.

27. Айвар Л.К., Трунов И.Л.. Нарушение конституционных прав граждан при дорожно-транспортных происшествиях. // Административное и муниципальное право. - 2010. - № 10. - С. 104-107.

28. Эсаулов С.В.. Международно-правовые основы принципа презумпции невиновности в уголовно-процессуальной деятельности полиции. // Полицейская деятельность. - 2011. - № 1. C. $104-107$

29. Акопджанова М.О. О роли уголовно-правовой науки в законотворческом процессе // Политика и Общество. -2014. - 1. - C. 76-81. DOI: 10.7256/18128696.2014.1.9217.

\section{References (transliteration):}

1. Alekseev, S. S. Voskhozhdenie k pravu. Poiski i resheniya/ S. S. Alekseev. - M.: NORMA, 2001. - 752 s.

2. Antonov, A.D. Teoreticheskie osnovy kriminalizatsii i dekriminalizatsii : Dis... kand. yurid. nauk : 12.00 .08 / A. D. Antonov. - M.: MGU im. M.V. Lomonosova, 2001. - $182 \mathrm{~s}$.

3. Gilinskii, Ya. I. Kriminologiya: teoriya, istoriya, empiricheskaya baza, sotsial'nyi kontrol'/ Ya. I. Gilinskii. - 2-e izd., pererab. i dop. - SPb.: Izdatel'stvo R. Aslanova «Yuridicheskii tsentr Press», 2009. - 504 s.

4. Esakov, G. A. Mens rea v ugolovnom prave SShA: istoriko-pravovoe issledovanie/ G. A. Esakov, predisl. O.F. Shishova. - SPb.: Izd-vo «Yuridicheskii tsentr Press», 2003. $-553 \mathrm{~s}$.

5. Zhalinskii, A. E. Ugolovnoe pravo v ozhidanii peremen: teoretiko-instrumental'nyi analiz/ A. E. Zhalinskii. 2-e izd., pererab. i dop. - M.: Prospekt, 2009. - 400 s.

6. Kristi, N. Predely nakazaniya / N. Kristi, per. s angl. V.M. Kogana, pod. red. Z.I. Lukovnikova. - M.: Progress, 1985. - $198 \mathrm{~s}$.

7. Lopashenko, N. A. Ugolovnaya politika/ N. A. Lopashenko. - M.: Volters Kluver, 2009. - 608 s.

8. Luneev, V. V. Prestupnost' XX veka: mirovye, regional'nye i rossiiskie tendentsii/ V. V. Luneev. - Izd. 2-e, pererab. i dop. - M.: Volters Kluver, 2005.-912 s. 


\section{Право и политика 4 (172) $\bullet 2014$}

9. Naumov, A. V. Forma ugolovnogo zakona i ee sotsial'naya obuslovlennost'/ A. V. Naumov, IGPAN // Problemy sovershenstvovaniya ugolovnogo zakonodatel'stva. - M., 1984. - S. $18-27$

10. Pan'ko K.K. Yuridicheskie konstruktsii kak kategorii vnutrennei formy (struktury) ugolovnogo prava// Pravo i politika. -2005 . - № 3. - S. $19-28$

11. Sitnikova, A. I. Zakonodatel'naya tekstologiya ugolovnogo prava: monografiya/ A. I. Sitnikova. - M.: Yurlitinform, 2011. - $344 \mathrm{~s}$.

12. Cherdantsev, A. F. Logiko-yazykovye fenomeny v prave, yuridicheskoi nauke i praktike/ A. F. Cherdantsev. - Ekaterinburg, 1993. - $192 \mathrm{~s}$.

13. Yuridicheskie konstruktsii i simvoly $\mathrm{v}$ ugolovnom prave/ L. L. Kruglikov, O. E. Spiridonova. - SPb.: Izdvo «Yuridicheskii tsentr Press», 2005. - $336 \mathrm{~s}$

14. Yu.V. Kozubenko Issledovanie mekhanizma ugolovnopravovogo regulirovaniya na mezhotraslevom urovne // LEX RUSSICA (RUSSKII ZAKON). - 2013. - 6. - C. 655-661.

15. A.I. Komarov, T.V. Yarovenko. Nekotorye problemy proverki versii prichineniya smerti iz ognestrel'nogo oruzhiya po neostorozhnosti // Pravo i politika. - 2009. - № 7 .

16. M.F. Luk'yanenko. «Dobrosovestnost'»: zakon i praktika primeneniya. Chast' vtoraya. Okonchanie // Pravo i politika. - 2009. - № 7 .

17. M. F. Luk'yanenko. «Dobrosovestnost'»: zakon i praktika primeneniya. Chast' 1 // Pravo i politika. 2009. - № 6.

18. V.A. Kalinovskii, A.I. Komarov. Proverka versii obvinyaemoi o prichinenii smerti po neostorozhnosti. // Pravo i politika. - 2008. - № 8.

19. Aliev Nazim Kazim ogly. Nekotorye voprosy sovershenstvovaniya norm o ponyatii i priznakakh souchas- tiya v ugolovnom zakonodatel'stve Azerbaidzhana // Pravo i politika. - 2013. - № 2. - S. 104-107. DOI: 10.7256/1811-9018.2013.02.8.

20. Pan'shin D.L.. Nekotorye aktual'nye voprosy primeneniya lisheniya prava upravleniya transportnymi sredstvami za administrativnye pravonarusheniya $\mathrm{v}$ oblasti dorozhnogo dvizheniya // Administrativnoe i munitsipal'noe pravo. - 2013. - № 10. - S. 104-107. DOI: 10.7256/1999-2807.2013.10.9112.

21. Bashirova A.F., Istratov A.A.. Pravovoe regulirovanie profilaktiki dorozhno-transportnogo travmatizma // Politseiskaya deyatel'nost'. - 2012. - № 2. - S. 104-107.

22. Moskvina Yu.V.. O prichinenii material'nogo ushcherba v rezul'tate dorozhno-transportnogo proisshestviya kak obstoyatel'stve, otyagchayushchem administrativnuyu otvetstvennost' // Administrativnoe i munitsipal'noe pravo. - 2011. - № 11. - S. 104-107.

23. Boreiko Yu.A.. Formirovanie sistemy ucheta administrativnykh pravonarushenii $\mathrm{v}$ oblasti dorozhnogo dvizheniya. // Politseiskaya deyatel'nost'. - 2011. - № 2. - S. 104-107.

24. Aivar L.K., Trunov I.L.. Narushenie konstitutsionnykh prav grazhdan pri dorozhno-transportnykh proisshestviyakh. // Administrativnoe i munitsipal'noe pravo. - 2010. - № 10. - S. 104-107.

25. Esaulov S.V.. Mezhdunarodno-pravovye osnovy printsipa prezumptsii nevinovnosti v ugolovnoprotsessual'noi deyatel'nosti politsii. // Politseiskaya deyatel'nost'. - 2011. - № 1. - S. 104-107

26. Akopdzhanova M.O. O roli ugolovno-pravovoi nauki v zakonotvorcheskom protsesse // Politika i Obshchestvo. - 2014. - 1. - C. 76 - 81. DOI: 10.7256/18128696.2014.1.9217. 